\title{
FUNGSI MAKNA DAN SIMBOL PADA KARWAR \\ (Function and Meaning of Karwar Symbol)
}

\author{
Rini Maryone \\ Balai Arkeologi Jayapua \\ maryonerini@gmail.com
}

\begin{abstract}
The existence of natural caves and niches wild in Biak and interesting enough, one of which is on the site Cave Yenukem, Makmakerbo village. On the site is found in the form of rock art paintings karwar on boulders. Karwar rock art painting is a relic of prehistoric ancestors, who came from the monumental character of the neolithic culture. Regarding the remains of rock art paintings karwar mystery writer tries to analyze the function, and symbols that can be known and studied by the younger generation, which contained educative function containing moral education for human life. The method of data collection is done with literature, field surveys, and analysis using Ethnoarchaeology approach. Painting sculpture karwar a relic of prehistoric ancestors. Karwar so basic concepts of trust in the Biak past so they created a form of sculpture called amflanir / karwar to commemorate those who died.
\end{abstract}

Keywords: function, meaning, symbol, karwar

\begin{abstract}
ABSTRAK
Keberadaan gua-gua alam maupun ceruk-ceruk alam di wilayah Biak cukup banyak dan menarik, salah satunya adalah di situs Gua Yenukem Desa Makmakerbo. Di situs tersebut ditemukan berupa lukisan seni cadas karwar pada bongkahan batu. Lukisan seni cadas karwar merupakan peninggalan dari nenek moyang dari jaman prasejarah, yang bercorak monumental berasal dari kebudayaan neolitik. Mengenai tinggalan seni cadas lukisan karwar penulis mencoba mengupas misteri akan fungsi, dan simbol sehingga dapat di ketahui dan dipelajari oleh generasi muda, yang termuat fungsi edukatif yang berisikan pendidikan moral bagi kehidupan manusia. Metode pengumpulan data dilakukan dengan studi pustaka, survei lapangan, dan analisis menggunakan pendekatan etnoarkeologi. Lukisan patung karwar merupakan peninggalan dari nenek moyang dari jaman prasejarah. Konsep kepercayaan karwar begitu mendasar pada orang Biak masa lampau sehingga mereka menciptakan suatu bentuk patung yang di sebut amflanirl karwar untuk memperingati orang yang meninggal.
\end{abstract}

Kata kunci: fungsi, makna, simbol, patung karwar

Tanggal masuk : : 12 September 2014

Tanggal diterima : 3 November 2014 


\section{PENDAHULUAN}

Peninggalan arkeologi adalah sisa-sisa hasil budaya fisik peninggalan nenek moyang yang masih dapat dilihat sampai saat ini. Peninggalan arkeologi tersebut merupakan warisan budaya dan merupakan data yang sangat penting untuk rekontruksi sejarah serta mengetahui proses perubahan masa lalu. Berkaitan dengan tinggalan arkeologi tersebut, di daerah Biak terdapat tinggalan arkeologi yang cukup banyak dan beragam, salah satu bentuk tinggalan arkeologi yang menarik dan sangat erat hubungannya dengan manusia pada masa lampau adalah berkaitan dengan pemanfaatan gua dan ceruk alam.

Salah satu bukti arkeologis penting mengenai seni terdapat di guagua dan ceruk-ceruk alam prasejarah. Keberadaan gua-gua alam maupun ceruk-ceruk alam di wilayah Biak cukup banyak dan menarik, hasil penelitan arkeologi yang pernah dilakukan di situs Gua Yenukem, Desa Makmakerbo ditemukan berupa lukisan manusia yang sedang menari, pada dinding luar gua sebelah barat, cangkang moluska dan terdapat lukisan karwar pada bongkahan batu yang berada di mulut gua. (Djami, 2009 : 13). Berdasarkan pada temuan arkeologis tersebut dapat mengungkapkan cerita kehidupan masyarakat Biak pada waktu itu. Mengenai tinggalan seni cadas lukisan karwar, penulis mencoba mengupas misteri akan fungsi, makna dan simbol lukisan seni cadas tersebut, sehingga dapat diketahui dan dipelajari oleh generasi muda, yang termuat fungsi edukatif yang berisikan pendidikan moral bagi kehidupan manusia.

Lukisan karwar yang ditemukan di Gua Yenukem, Desa Makmakerbo merupakan peninggalan dari nenek moyang dari jaman prasejarah yang dipahatkan pada batu memiliki kekayaan ornamen yang unik. Menurut Gustami (1978) ornamen adalah komponen produk seni yang ditambahkan atau sengaja dibuat untuk tujuan sebagai hiasan. Bedasarkan pengertian itu ornamen merupakan penerapan hiasan pada suatu produk. Bentuk-bentuk hiasan yang menjadi ornamen tersebut fungsi utamanya adalah untuk memperindah benda produk atau barang yang di hias.

Penambahan ornamen pada sebuah produk pada umumnya diharapkan penampilannya lebih menarik, dalam arti estetis, dan lebih bernilai serta meningkatkan penghargaan terhadap produk benda bersangkutan, baik secara spiritual maupun material. Selain itu, tidak jarang ornamen yang dibubuhkan pada suatu produk memiliki nilai simbolik mengandung maksudmaksud tertentu, sesuai dengan tujuan dan gagasan pembuatnya, sehingga dapat meningkatkan status sosial kepada yang dimilikinya. Dengan demikian, sesungguhnya ornamen tidak dapat dipisahkan dari latar belakang sosial budaya masyarakat bersangkutan. Karena itu ciri-ciri yang jelas dan berbeda antara satu dengan yang lain sesuai dengan masyarakat pendukungnya, manifestasi dari sistem gagasan yang menjadi acuan.

Pengertian ornamen Nusantara menunjuk pada bermacam bentuk ornamen yang tersebar di berbagai wilayah tanah air, pada umumnya bersifat tradisional yang terdapat di setiap daerah memiliki kekhasan dan keragamannya masing-masing. Karena itu ornamen Nusantara memiliki ciri-ciri kedaerahan sesuai dengan cita rasa masyarakat setempat. Ornamen Nusantara merupakan keragaman dan kekayaan ungkapan budaya Indonesia. Disamping terdapat perbedaanperbedaan bentuk ornamen yang terdapat di berbagai daerah, terdapat pula persamaan-persamannya, misalnya tentang beberapa jenis motif ornamen, pola susunan yang 
setangkup, warna, bahkan mungkin pada nilai simbolisnya.

Fungsi simbolis ornamen pada umumnya dijumpai pada produkproduk benda upacara atau bendabenda pusaka dan bersifat keagamaan atau kepercayaan, menyertai nilai estetisnya. Ornamen yang menggunakan motif kala, biawak, naga, burung atau garuda misalnya pada karya-karya masa lampau berfungsi simbolis.

Untuk mengetahui suatu simbol dari suatu benda maka kita mengerti terlebih dahulu arti simbol itu sendiri, Ardhendu Sekhar Gosh dalam Titib (2001 : 63) menyatakan bahwa kata simbol berasal dari kata "symbolon" (bahasa Yunani) yang berarti tanda dan dengan tanda itu seseorang mengetahui atau mengambil kesimpulan tentang sesuatu. Dalam bahasa Sanskerta kata simbol adalah 'pratika' yang mengandung arti yang datang ke depan, yang mendekati. Dengan demikian kata ini mengandung makna menunjukkan, menampilkan atau menarik kembali sesuatu dengan analogi kualitas kepemilikan atau dengan mengasosiasikan ke dalam fakta atau pikiran. Selain kata 'pratika', kata simbol dapat dijumpai beberapa padanannya di dalam bahasa Sanskerta, antara lain: cihnam, laksanam, lingam, samjna, pratirupa.

Simbol adalah sesuatu yang perlu ditafsir maknanya dan pada giliran berikutnya dibagikan oleh dan kepada masyarakat dan diwariskan kepada anak cucunya (Susanto, 1990 : vi-vii). Dibyasuharda (1990 : 22) dengan mengutip pendapat Carl Gustav Jung mengatakan bahwa simbol mengandaikan bahwa ekspresi yang terpilih adalah formulasi yang paling baik akan sesuatu yang relatif tidak terkenal, namun hal itu diketahui sebagai hal yang ada atau diharapkan ada. Selama suatu simbol hidup, simbol itu adalah ekspresi suatu hal yang tidak dapat ditandai dengan tanda lebih tepat. Simbol hanya hidup selama simbol itu mengandung arti bagi kelompok manusia yang besar sebagai sesuatu yang mengandung milik bersama sehingga simbol menjadi simbol sosial yang hidup dan pengaruhnya menghidupkan.

Triguna (1997: 64) juga mengatakan bahwa simbol adalah suatu hal atau keadaan yang merupakan pengantaran pemahaman terhadap objek. Manifestasi serta karakteristik dari simbol tidak terbatas pada isyarat fisik tetapi juga berwujud pada penggunaan kata-kata yaitu simbol suara yang mengandung arti serta bersifat standar. Simbol juga seringkali memiliki makna mendalam yaitu konsep yang paling bernilai dalam kehidupan suatu masyarakat.

Karya seni tidak hanya terbatas dari karya-karya yang indah dan menarik menurut subyektivitas manusia, tetapi yang lebih penting adanya aspek simbol-simbol, fungsi dan dimensi kognitif. Karya seni merupakan interpretasi manusia terhadap gejala alam melalui pengalaman, penghayatan, dan daya kreativitas, ke dalam bentuk rupa, gerak dan suara dengan kebebasan interpretasi penikmatnya. Beliau mengatakan bahwa seni adalah suatu yang mengandung unsur keindahan dan simbolisasi, sedangkan karya seni berkaitan dengan segala hal yang mempengaruhi maupun dipengaruhi (Wardaninggar, 2002 : 63).

Penulis memasukkan kerangka konsep ini agar dapat dijadikan sebagai bahan perbandingan dengan tujuan membuka pemahaman akan makna simbol, secara khusus lukisan karwar di dalam kehidupan masyarakat Biak pada umumnya agar dapat membantu penulis dalam mengkaji lukisan karwar pada masa lalu dan pada masa sekarang, lukisan karwarl patung karwartersebut sudah pasti mempunyai 
makna tersendiri dari masyarakat pendukungnya. Yang dimaksud dengan fungsi dalam penulisan ini adalah segala sesuatu yang berkaitan dengan kegunaan patung karwar dalam sistem kehidupan masyarakat, baik kegunaan sehari-hari, religius, kegunaan dari dulu sampai sekarang.

Berdasarkan pada uraian latar belakang di atas maka, tulisan ini akan membahas fungsi, dan simbol lukisan seni cadas karwar serta simbol edukatif yang berisikan pendidikan moral. Data yang digunakan berupa hasil observasi lapangan, wawancara serta studi kepustakaan. Pendekatan yang digunakan dalam penelitian ini adalah pendekatan etnoarkeologi dengan memanfaatkan data etnografi sebagai analogi untuk membantu memecahkan masalah arkeologi.

\section{PEMBAHASAN}

Desa Makmakerbo adalah tanah ulayat milik marga Makmaker, Arfayan, Fairyo, dan Amsek (Djami, 2009 : 8). Secara administratif Desa Makmakerbo termasuk dalam wilayah Kabupaten Biak Numfor. Biak dari sisi historis berasal dari istilah dalam bahasa Biak yaitu "sub we vyak (byak) iwa" yang dapat di artikan "Byak negeri yang timbul di atas permukaan laut" (Assa dkk, 2013 : 15), dan menyebutnya dengan istilah: De eilanden van negen stammen" yang artinya kepulauan yang didiami sembilan suku sehingga Biak juga di sebut "Negeri Sembilan" (The islands of nine tribes). Sembilan suku itu antara lain: suku Padaido atau Anovo (an artinya makan jadi anovo artinya makanan yang berlimpahlimpah, suku Fairyo di pedalaman Makmakerbo, suku Byak, suku Samber, suku Manwor, suku Mnuwar, suku Swandiwe, suku Wombonda, dan suku Poiru (Assa, 2012 : 226-227).

Biak memiliki tinggalan arkeologi yang cukup banyak dan beragam, salah satu bentuk tinggalan arkeologi yang menarik dan sangat erat hubungan dengan manusia pada masa lampau adalah berkaitan dengan pemanfaatan gua dan ceruk alam. Keberadaan guagua alam maupun ceruk-ceruk alam dari hasil penelitan arkeologi yang pernah dilakukan di situs Gua Yenukem, Desa Makmakerbo ditemukan lukisan karwar pada bongkahan batu yang berada di mulut gua (Djami, 2009 : 13). Bila dilihat bahwa lukisan pada batu atau seni cadas, sebagai salah satu data arkeologi yang diterakan pada dinding gua dan ceruk serta tebing, dianggap sebagai catatan sejarah manusia yang sangat menakjubkan.

Tidak dapat disangkal lagi bahwa seni pada batu atau seni cadas (rock art) merupakan salah satu bentuk data arkeologi yang sangat penting guna mengungkapkan kehidupan masyarakat manusia pendukungnya pada masa lampau, terutama sekali pada masa prasejarah. Karya seni yang diterakan pada permukaan cadas ini tidak saja dianggap sebagai tinggalan yang mengandung banyak informasi tentang perilaku kehidupan manusia, tapi juga lebih dipandang sebagai salah satu bukti pencapaian cita rasa seni manusia yang tetuang di media batu, baik dalam bentuk gambar, goresan maupun pahatan. Budaya seni cadas ini memiliki seluas sebaran meliputi hampir sebagian belahan dunia, mulai dari Eropa Barat, Asia Daratan dan Asia Kepulauan, Australia dan Pasifik sehingga memberikan kesan seni cadas sebagai ungkapan cira rasa seni yang bersifat universal (Prasetyo, 2004 :27).

Lukisan karwar yang ditemukan di Gua Yenukem, Desa Makmakerbo ini merupakan peninggalan dari nenek moyang dari jaman prasejarah yang dipahatkan pada batu memiliki kekayaan ornamen yang unik. Kalau dilihat secara keseluruhan bahwa di Indonesia dengan berbagai suku bangsa memiliki kekayaan ornamen 
tidak saja yang ditemukan di gua dan ceruk tetapi juga yang terdapat pada benda produk, pada tenun sulaman, anyaman, ukiran, arsitektur dan sebagainya (Fisher dalam Kartiwa, 1993).

Kajian tentang ornamen Nusantara pertama kali dilakukan oleh Van der Hoop. Penggambaran sosok manusia sebagai seorang tokoh atau nenek moyang, yang dipahatkan pada batu, pada artefak peninggalan prasejarah, ditemukan di wilayah Nusantara misalnya di Sumatra Selatan berupa peninggalan batu gajah yang melukiskan seseorang penunggang gajah membawa nekara dan di pinggangnya tergantung sebilah pedang. Ditemukan pula di Lembah Bada, Sulawesi Tengah, yaitu patungpatung nenek moyang paliodo dari batu monolit. Patung batu dari Nias dan Batak Sumatera utara, patung kayu dari Kalimantan timur dan patung Mbis dari suku Asmat, dan juga patung korwar ini, merupakan penggambaran sosok manusia dalam kesenian Nusantara yang bercorak monumental. Patung nenek moyang yang bercorak monumental berasal dari kebudayaan neolitik dan oleh para sarjana Barat disebut sebagai patung bertipe Polinesia, jejak-jejaknya masih terlihat jelas dan diterapkan pada ornamen nusantara, terutama di daerah-daerah pedalaman yang belum tersentuh oleh kebudayaan yang datang dari India.

Kehadiran motif manusia sebagai penggambaran nenek moyang dalam ornamen Nusantara terkait dengan pemujaan leluhur dan dimaksudkan untuk persembahan. Kepercayaan ini sangat mensakral dan masih dapat dilacak jejak-jejaknya pada bagian suku-suku bangsa yang mendiami kepulauan Nusantara. Simbol kekuatan gaib untuk menolak bala. Motif manusia dalam seni hias dipercaya memiliki kekuatan magis yang dapat melindungi pemilikinya dari gangguan setan atau roh jahat.

\section{Penggambaran motif manusia} dapat dalam bentuk manusia seutuhnya atau bentuk sebagian saja. Penggambaran sosok manusia secara utuh antara lain dapat dilihat pada ukir kayu Asmat, ukir batu dan tenun Sumba, relief pada dinding candi. Yang berbentuk sebagian, dalam arti tidak utuh, misalnya motif wajah atau topeng, mata, telapak tangan, atau bagian tubuh yang lain, bahkan ada pula yang menggambarkan bagianbagian vital. Dalam hubungan ini, motif wayang termasuk motif manusia karena pada dasarnya wayang merupakan penggambaran tokoh nenek moyang atau manusia. Penggambaran sosok manusia pada daerah-daerah yang relatif belum tersentuh pengaruh asing, pada umumnya masih meneruskan gaya "primitif". Biasanya sosok manusia dilukiskan secara frontal, menghadap ke depan. Kedua kaki dan tangan dalam sikap menentang.

Karwar adalah patung manusia dalam posisi duduk atau berdiri dengan kepala yang besar. Wajahnya dikenal melalui hidung yang tajam (mancung dan mulut yang lebar. Patung ini dibuat sebagai kenang-kenangan bagi seseorang yang telah meninggal dunia, yang semasa hidupnya telah banyak berjasa bagi keret ataupun keluarganya (Rumansara dkk, 2012 : 42). Patung karwar berfungsi sebagai lambang kehadiran roh para nenek moyang yang telah meninggal. Mereka percaya bahwa roh orang mati/ orang yang sudah meninggal dapat dipanggil untuk memberikan petunjukpetunjuk penting seperti masa panen dan penyembuhan penyakit. Hal ini dilakukan melalui perantaraan dukun setempat, dengan patung karwar sebagai medianya.

Akan tetapi korwar ini harus membuktikan kegunaannya pada anggota-anggota klen dengan menolak bahaya dan memberi bantuan ketika berburu dan menangkap ikan. Dalam 
pandangan mereka roh-roh orang mati itu mempunyai peran tertentu bagi kehidupan manusia. Roh orang mati tersebut dapat mewakili untuk menempat di dunia roh, dunia awan dan dunia angin. Roh orang mati juga dapat berubah menjadi hewan bagi kehidupan dan kesejahteraan umat manusia. Selain itu, roh orang mati juga berperan untuk menjaga keteraturan adat istiadat dalam kehidupan manusia sehingga orang-orang yang melanggar adat-istiadat mendapat hukuman dari roh para leluhur. Bila tidak dipelihara sebagai anggota keretnya sebagai mandur, yaitu roh jahat. Dan sebagai kaki tangan korano faknik. Akhirnya roh-roh jahat yang tidak dipelihara dapat dipakai sebagai alat dalam perbuatan-perbuatan dan perbuatan asosial dari dukun-dukun sihir. Rohroh ini lalu dapat dipanggil oleh para mon atau dukun dari anggota keret lain (Peyon, 2012 :61-62).

Apabilaadaanggotakeluargayang meninggal dunia, pengukir, pematung diminta untuk memahat sebuah karwar sebagai tempat bersemayam sang roh yang telah meninggal. Dengan kerja seniman tersebut, seniman tersebut akan dibayar berupa: piring porselin, gelang logam, gelang siput, makanan dan parang. Nico Asariba mengatakan bahwa konsep kepercayaan karwar, begitu mendasar pada orang Biak masa lampau sehingga mereka menciptakan suatu bentuk patung yang disebut amfianir/religius karwar untuk memperingati anggota keluarga yang meninggal. Mereka berpendapat bahwa manusia mempunyai satu tubuh dan dua roh, yaitu jasmaniah (baken saprop), roh (rur) dan bayangan roh (nin). Seseorang yang masih hidup berarti jasmaniah, ruh dan nin menjadi satu, apabila saat kematian seseorang berarti jasmaniah akan rusak dan dipindahkan ke suatu tempat khusus yang disebut yen aibui (dunia jasad). Yen Aibui adalah tempat orang mati akan dibangkitkan dari kematian atau yen aibui sebagai pintu masuknya roh (rur) dan (nin) untuk bertemu kembali dengan jasad yang akan bangkit kembali dalam bentuk yang baru.

Kebangkitan yang dibawa oleh Manseren koreri, saat orang mati, roh (rur) akan pergi bersemayam di dunia roh (sup romawi) dan di langit (nanggi), sedangkan bayangan roh (nin) berdiam di alam karwar bersama orang hidup, dengan demikian orang Biak membuat patung menyerupai orang hidup sebagai tempat berdiam nin, sehingga nin tidak berkeliaran bersama dengan orang hidup diantara anggota keluarga mereka. Untuk menjaga kekeluargaan ini, maka upacara adat (ritus) merupakan faktor penting. Mereka percaya bahwa roh karwarl arwah-arwah ini memberi kekuatan untuk menjaga keluarga, memelihara kebun, mendatangkan hujan, menjauhkan penyakit, dan juga menyusahkan, menyakiti dan menakutnakuti orang yang masih hidup. Jadi apabila seseorang mengalami bencana atau penyakit, ide pertama yang muncul dipikiran mereka ialah yang bersangkutan telah menyimpang dari tatanan spiritual, sebaliknya seseorang yang berhasil dalam usaha/hidupnya karena mengadakan hubungan/ kontak dengan dunia karwar.

Patung karwar terdiri atas Amfianir patung kayu yang dibuat untuk nin (roh bayangan) dan dari golongan masyarakat biasa. Amfianir opur bukor adalah patung roh yang bagian kepalanya berisi tengkorak dari orang-orang terkemuka atau khusus untuk para kepala suku dan ketua-ketua adat klen atau marga. Cara mengambil tengkorak setiap daerah berlainan.

Dalam patung disediakan tempat terbuka untuk tengkorak, tengkorak ini dapat dimasukan dari belakang, ke bawah atau dari depan. Kalau dimasukan dari depan, tengkorak itu dipakai sebagai muka, sedangkan 
dalam hal yang lain muka itu harus di ukir dalam kayu (ukuran $50 \mathrm{~cm}$ ).

\section{Perkembangan karwar}

Kepercayaan orang Biak terhadap karwar, mulai berkurang setelah Injil masuk di Papua pada tanggal 5 Februari 1855, dengan kesadaran dan kemauan sendiri mereka memusnahkan rumahrumah adat (sram-ram/ rum sram) termasuk patung-patung karwar. Tetapi pada tahun 1960 patung karwar mulai digali kembali sebagai warisan budaya, namun patung tersbut sudah beralih fungsi, tidak lagi berfungsi sebagai patung pemujaan roh orang mati tetapi berfungsi sebagai patung hiasan interior dan komersial semata.

Patung karwar berkembang pada dua masa, sehingga fungsi patung karwar dibedakan dalam 2 periode, yaitu: periode sebelum tahun 1875, dan periode sesudah tahun 1960 (Kama, 1972 : 303). Periode pertama sebelum tahun 1875 , adalah periode orang Biak masa lalu yang masih percaya akan kekuatan dan kehadiran roh nenek moyang. Periode sesudah tahun 1960, merupakan fase/ masa kehidupan kembali patung karwar. Karena sekitar 100 tahun patung karwar hilang dan punah dari pembuatan dan peredaraannya akibat pengaruh agama Nasrani.

Fungsi patung karwar pada periode pertama 1875 , sebagai patung peringatan anggota keluarga yang telah meninggal, sebagai tempat bernaungnya (bersemayamnya) roh nenek moyang sebagai simbol penyatu rasa kekeluargaan yang erat pada upacara-upacara karwar. Sebagai pelindung, untuk meminta nasehat, menyertai perjalanan dalam pelayaran, memberi kesuburan, menjauhkan penyakit, menyertai perburuan di darat dan laut. Sebagai pusat roh moyang yang merupakan pusat perhatian religius.
Fungsi patung karwar pada periode ke-dua yaitu tahun 1960, sebagai bahan ekspresi seniman untuk menciptakan bentuk-bentuk baru. Sebagai bahan untuk komersial/ souvenir. Sebagai bahan untuk dekorasi interior ruang tamu dan hotelhotel serta kantor-kantor. Sebagai kekayaan seni budaya di museum, dan sebagai bahan budaya penelitian budaya dan pendidikan.

Arti simbolisasi yang divisualisasi dalam bentuk patung karwar, adalah kepala patung karwar yang lebih besar dan silinder itu menyerupai tengkorak, yang melambangkan dunia orang mati. Mata kecil, ada beberapa patung yang matanya diisi manik-manik berwarna kuning dan putih atau dengan pecahan piring, patung itu harus ditutup penglihatannya. Hal ini merupakan arti simbol dari mayat orang meninggal yang ditutup matanya supaya tidak melihat dengan pandangan memanggil orang yang masih hidup untuk ikut ke dunia bawah (dunia orang mati).

Patung yang duduk melipat kaki, simbolisasi dari mayat yang dilipat dan diikat erat-erat, supaya tidak menendang anggota keluarga lain untuk ikut meninggal. $\quad \mathrm{P}$ a $\mathrm{t} \mathrm{u} \mathrm{ng}$ yang tangannya menopang dagu adalah simbol seorang pemikir. Patung karwar tidak mempunyai alat kelamin, karena roh orang mati tidak berkembang biak dan alat kelamin merupakan lambang kenajisan atau dosa.

Atribut (aksesories) yang dipakai/ dipegang patung karwar memberi arti tentang kapasitas dan jenis pekerjaan si mati antara lain: buaya lambang kesatria, jadi roh yang ada dalam seseorang panglima perang. Ular melambangkan seorang dukun (obatan). Tanaman melambangkan seorang dalam kepemimpinan yang melindungi warganya. Patung karwar tidak bersusun simbolisasi kehidupan individu (perorangan). Bentuk sudut 
yang tajam adalah melambangkan kekerasan dan kekuasaan. Patung karwar yang berdiri adalah patung seorang pemimpin upacara-upacara fan nanggi (mon).

Kearifan budaya patung karwar adalah energi potensial dari sistem pengetahuan kolektif masyarakat Biak untuk hidup di atas nilai-nilai yang membawa kelangsungan hidup yang berperadaban; hidup damai, hidup rukun; hidup bermoral; hidup saling asih-asah dan asuh; hidup dalam keragaman, hidup penuh maaf dan pengertian; hidup toleran, harmoni dengan lingkungan; hidup dengan orientasi nilai-nilai yang membawa pada pencerahan; hidup untuk menyelesaikan persoalan-persoalan berdasarkan mozaik nalar kolektif sendiri. Kearifan seperti itu tumbuh dari dalam lubuk hati masyarakat sendiri itulah bagian terdalam dari kearifan lokal. Dengan melihat pentingnya nlainilai di dalam fungsi, makna dan simbol pada patung karwar, diharapkan merupakan perangkat dalam upaya peningkatan mental moral bangsa yang menjadi lebih bergairah dan memberikan sumbangan yang berarti bagi generasi muda di Papua.

\section{PENUTUP}

Peninggalan arkeologi adalah sisa-sisa hasil budaya fisik peninggalan nenek moyang yang masih dapat dilihat sampai saat ini. Peninggalan arkeologi tersebut merupakan warisan budaya dan merupakan data yang sangat penting untuk rekonstruksi sejarah serta mengetahui proses perubahan masa lalu. Salah satu bukti arkeologis penting mengenai seni terdapat di guagua dan ceruk-ceruk alam prasejarah, hasil penelitian arkeologi yang pernah dilakukan di situs Gua Yenukem, Desa Makmakerbo ditemukan berupa lukisan karwar pada bongkahan batu yang berada di mulut gua. Berdasarkan pada temuan arkeologis seni cadas lukisan karwar pada bongkahan batu tersebut dapat mengungkapkan fungsi, dan simbol, serta mengungkapkan cerita kehidupan masyarakat Biak pada waktu itu.

Lukisan patung karwar merupakan peninggalan dari nenek moyang dari jaman prasejarah, yang bercorak monumental berasal dari kebudayaan neolitik, yang disebut sebagai patung bertipe Polinesia, jejak-jejaknya masih terlihat jelas dan diterapkan pada ornamen Nusantara, terutama di daerah-daerah pedalaman. Konsep kepercayaan karwar begitu mendasar pada orang Biak masa lampau sehingga mereka menciptakan suatu bentuk patung yang di sebut amflanirl karwar untuk memperingati orang yang meninggal, tetapi dewasa ini konsep kepercayaan tersebut telah bergesar dengan masuknya Nasrani, patung karwar telah beralih fungsi dari patung yang di jadikan sebagai patung pemujaan menjadi sebuah patung hiasan interior dan komersial semata.

Masyarakat lokal sebagai pemilik budaya tersebut hendaknya lebih ditingkatkan kesadarannya akan makna yang terkandung di dalamnya sehingga bijak dalam mengelola budayanya serta lingkungannya yang ada di sekitarnya, yang patut dipelihara dan dijunjung, tidak saja oleh masyarakat pemiliknya tapi juga masyarakat luar yang hendak berinteraksi dengan mereka. 


\section{DAFTAR PUSTAKA}

Assa, Rhibka Veibe dan Rasyd Abdul Ramla. 2005. Asal-usul Sirep Sebagai Budaya Orang Biak di Kampung Wouna, Distrik Warsa (Kajian Cerita Rakyat tentang Alat Musik Tifa dalam Tinjauan Lingkungan Hidup). Balai Pelestarian Sejarah dan Nilai Tradisional Jayapura.

Assa, Rhibka Veibe. 2013. Tanaman 'Pokem' dalam Tradisi Lokal Etnis Biak di Pulau Numfor Kabupaten Biak Numfor. Balai Pelestarian Sejarah dan Nilai Tradisional Jayapura.

Ap, Lamech, dkk. 2005. Budaya Masyarakat Suku Bangsa Biak di Kabupaten Biak Numfor. Jayapura: BKSNT Jayapura.

Djami, Erlin Novita Idje. 2009. Berita Penelitian Arkeologi No 07. Gua-gua Prasejarah di Desa Makmakerbo. Balai Arkeologi Jayapura.

Kartika, Suwati. 1993. Tenun Ikat. Cetakan ke-3. Jakarta: Djambatan.

Kamma Ch Frerk. 1972. Koreri. Gerakan Mesianis di Daerah Berbudaya Biak Numfor.

Peyon Ibrahin, dkk. 2012. Tradisi Penangkapan Ikan Masyarakat Numfor di Kabupaten Biak Numfor Provinsi Papua. Balai Pelestarian Sejarah dan Nilai Tradisional Jayapura Papua.

Prasetyo, Bagyo, dkk. 2004. Religi Pada Masyarakat Prasejarah Indonesia. Proyek Penelitian dan Pengembangan Arkeologi.

Rumansara, Enos dkk, 2012. Tradisi Wor di Kabupaten Biak Numfor, Provinsi Papua. Balai Pelestarian Sejarah dan Nilai Tradisional Jayapura.

www.srianindiatinursastri.com diakses pukul 10:30 WIT, tanggal 14 Maret 2014.

Wardaninggar, Kusuma Apriastuty Bernadeta. 2002. Walannae Jurnal Arkeologi Sulawesi Selatan dan Tenggara vol. V 8 Juni. Aktualisasi Pola Hias Prasejarah dalam Konteks Masa Kini. Balai Arkeologi Makassar.

Www.nicoasaribab.com diakses pukul 10: 30 WIT, tanggal 14 Maret 2014. 